\title{
Peningkatan Skill Teknologi Pengrajin Produk Unggulan Kabupaten Purbalingga pada Kerajinan Batik, Kerajinan Bambu dan Seni Patung
}

\author{
Kurniawan $^{1}$, Nurdiawati ${ }^{2}$, Rianto $^{3}$, Varahdilah $^{4}$ \\ ${ }^{1}$ Program Studi Akuntansi, Universitas Peradaban \\ ${ }^{2}$ Program Studi Pendidikan Bahasa Inggris, Universitas Peradaban \\ ${ }^{3}$ Program Studi Manajemen, Universitas Peradaban \\ ${ }^{4}$ Program Studi Pendidikan Guru Sekolah Dasar, Universitas Peradaban \\ e-mail: ${ }^{1}$ wawan1020@yahoo.co.id, ${ }^{2}$ dedenurdiawati7@gmail.com, \\ ${ }^{3}$ riantosugeng@yahoo.com, ${ }^{4}$ noviea011@gmail.com
}

\begin{abstract}
Abstrak
Kabupaten Purbalingga memiliki potensi unggulan diantaranya adalah pariwisata, pertanian, manufaktur, kerajinan tangan, makanan olahan, perdagangan dan jasa. Permasalahan yang dihadapi diantaranya biaya bahan baku yang tinggi, penanganan bahan baku belum maksimal, rendahnya pemanfaatan bahan baku lokal, kapasitas produksi terbatas, pengetahuan yang rendah tentang teknologi tepat guna, jangkauan pemasaran masih sedikit, potensi pasar belum dimaksimalkan, tidak tersedia sistem penjualan yang baik, peralatan masih sederhana, keterampilan masih terbatas, belum adanya pembukuan akuntansi dan laporan keuangan, belum memiliki status badan hukum yang jelas dan kesulitan mendapatkan akses modal. Melalui metode pelatihan dan penyuluhan beberapa kegiatan yang dilaksanakan diantaranya pelatihan teknologi batik printing malam dingin, pelatihan serut bambu menggunakan mesin, pelatihan pewarnaan remasol, penyuluhan penanganan bahan baku, membangun kemitraan antar kelompok mitra, dan kegiatan pendampingan yang terus menerus, untuk meningkatkan kualitas dan omset mitra menjadi meningkat.
\end{abstract}

Kata kunci: Produk Unggulan Kabupaten Purbalingga, Batik, Kerajinan Bambu dan Seni Patung

\section{PENDAHULUAN}

Berdasarkan data Dinas Koperasi dan UMKM kabupaten Purbalingga, tahun 2017 jumlah pelaku UMKM di Purbalingga sebanyak 86.885. Unit usaha dengan tingkat penyerapan kerja sebesar 346.126 tenaga kerja, semakin banyaknya unit usaha, menjadikan tidak sepenuhnya semua UMKM mendapatkan pendampingan dari pemerintah daerah. Berbagai program telah diselenggarakan oleh dinas koperasi dan UMKM Kabupaten Purbalingga, namun arah kebijakan ke peningkatan teknologi UMKM masih sangat jarang.

Sejalan dengan Visi Misi dan Sasaran RPJMD 2016-2021 Kabupaten Purbalingga, Visi Kepada Daerah Kabupaten Purbalingga Tahun 2016-2021 adalah Purbalingga yang 
Mandiri dan Berdaya Saing Menuju Masyarakat Sejahtera yang berakhlak Mulia, memiliki Misi Meningkatkan Kesejahteraan dan Pemerataan Ekonomi Masyarakat, salah satu sasarannya adalah meningkatkan daya saing usaha kecil mikro. Daya saing membutuhkan strategi, bagaimana memproduksi produk dengan biaya rendah, usaha yang potensi berdasarkan wilayah daerah kabupaten yang menguntungkan, dan melakukan inovasi yang meningkatkan kemampuan unit usaha, Aroanto (2013).

Kabupaten Purbalingga memiliki potensi UMKM yang beragam diantaranya mulai kerajinan bulu mata, kerajinan sapu glagah, batik, knalpot, tas, alas kaki, gula kristal, konveksi border, kerajinan kayu serta kerajian bambu. Pemerintah daerah lebih memperhatikan kepada peningkatan kinerja unit usaha yang berada pada wilayah garis merah, untuk memeratakan kesempatan kerja, dan perkembangan ekonomi wilayah kabupaten. Beberapa unit usaha yang berada pada garis merah diantaranya adalah Batik Sekarsari, Istana Bambu dan Akar Wijaya.

Batik Sekarsari sudah berdiri cukup lama, yakni pada tahun 2008, beberapa pemuda berkomitmen untuk mendirikan kelompok usaha batik Sekarsari diantaranya adalah Edi, Mulyono dan Farijal Ikhsan, berawal dari kegiatan PNPM, sebagai kegiatan pendampingan pada usaha kecil, yang saat itu menyelenggarakan kegiatan pelatihan batik di Desa Gambarsari. Jumlah anggota aktif saat ini untuk Sekarsari adalah 20 orang, anggota tersebut aktif untuk memproduksi batik maupun pewarnaan. Beberapa keteramilan dasar yang telah dimiliki kelompk batik Sekarsari diantaranya adalah telah mampu untuk memproduksi batik, membuat desain batik, mencanting kain, melorod lilin dan mewarnai. Beberapa produk unggulan yang dihasilkan diantaranya adalah batik tulis, batik cap dan kombinasi, batik pewarnaan alam dan sintesis.

Kelompok Batik Kelompok kerajinan berikutnya adalah Istana Bambu, Hentri Guntoro dipercayai sebagai ketua kelompok dengan anggota sebanyak 30 orang yang tersebar di beberapa desa di Kecamatan Kemangkon, Hentri Guntoro tergolong aktif di beberapa kegiatan Expo untuk memperkenalkan produk unggulan Kabupaten Purbalingga khususnya kerajinan bambu, mulai berdiri tahun 2004 sampai dengan sekarang tetap konsisten mengembangkan kerajinan bambu yang berdasarkan hasil wawancara menjelaskan tidak pernah mengalami sepi pembeli, berdiri di desa Desa Bakulan Rt. 11/ Rw. 05 Kecamatan Kemangkon, dengan produk unggulan tutup saji, penampan, alas makan Batik bambu, piring sada, gazebo, background pengantin, tempat tisu, kursi teras, miniature gazebo, dan banyak produk lain yang dihasilkan kelompok usaha ini.

Sekarsari saat ini juga sedang mengembangkan keterampilan batiknya menggunakan bahan gutha tamarin atau malam dingin, menggunakan bahan baku serbuk biji asam, sebagai 
metode baru yang lebih cepat untuk bahan membatik, dengan harapan Sekarsasi dapat menerima pesanan dalam jumlah besar, prosesnya produksi sangat mudah, beberapa serbuk biji asam dicampur dengan sedikit mentega dan air panas, kemudian di adon, setelah agak kalis dan tidak terlalu kental maka gutha tamarin siap untuk digunakan produksi batik malam dingin. Teknologi ini dapat mempercepat proses produksi sebanyak 150 potong dalam satu jam, sehingga dapat untuk memenuhi pesanan kain seragam kantor di Kabupaten Purbalingga, seragam sekolah SMP atau SMK dan produksi kapasitas besar dengan motif sama.

Kelompok kerajinan berikutnya adalah Istana Bambu, Hentri Guntoro dipercayai sebagai ketua kelompok dengan anggota sebanyak 30 orang yang tersebar di beberapa desa di Kecamatan Kemangkon, Hentri Guntoro tergolong aktif di beberapa kegiatan Expo untuk memperkenalkan produk unggulan Kabupaten Purbalingga khususnya kerajinan bambu, mulai berdiri tahun 2004 sampai dengan sekarang tetap konsisten mengembangkan kerajinan bambu yang berdasarkan hasil wawancara menjelaskan tidak pernah mengalami sepi pembeli, berdiri di Desa Bakulan Rt. 11/ Rw. 05 Kec. Kemangkon Kabupaten Purbalingga, dengan produk unggulan tutup saji, penampan, alas makan batik bambu, piring sada, gazebo, background pengantin, tempat tisu, kursi teras, miniature gazebo, dan banyak produk lain yang dihasilkan kelompok usaha ini.

Mitra berikutnya adalah kelompok Usaha Akar Wijaya, Akar Wijaya adalah kerajinan tangan pembuatan seni patung, yang sudah digeluti sejak 3 tahun yang lalu, atau tahun 2015, yang diketuai oleh bapak Nyarjan Prianto yang beralamat di Desa Kedungbenda Rt. 03/ Rw. 04 Kecamatan Kemangkon Kabupaten Purbalingga. Awalnya kelompok ini adalah pengrajin kayu atau sering disebut sebagai tukang kayu, semakin hari persaingan terhadap tukang kayu semakin banyak, sehingga diprakarsai oleh bapak Prianto mulai merintis untuk pembuatan seni patung.

Kelompok usaha Sekarsari, Istana Bambu dan Akar Wijaya memiliki beberapa masalah yang sama secara umum pada ketiga mitra ini adalah biaya bahan baku yang harganya tergolong tinggi, penanganan bahan baku kualitas rendah belum maksimal, rendahnya pemanfaatan bahan baku lokal menjadi produk bernilai, kapasitas produksi yang terbatas, pengetahuan peralatan dan teknologi tepat guna yang rendah, sumber daya manusia yang terlatih masih sedikit, biaya operasional proses produksi yang tinggi, keterampilan meggunakan malam dingin masih rendah, keterampilan dalam pewarnaan remasol terhadap produk hasil kerajinan yang masih rendah, keterampilan pengrajin bambu yang masih rendah terhadap teknik pewarnaan Batik pada media bambu, dan peralatan produksi yang tidak menunjang nilai produk. 


\section{METODE}

Berdasarkan kesepakatan antara mitra dan tim pengabdian Universitas Peradaban, beberapa program pelatihan dan penyuluhan yang akan di selenggarakan untuk meningkatkan keberlanjutan usaha kecil dan menengah dipetakan menjadi tiga tahap yaitu kemitraan, peningkatan kualitas dan manajemen, pengambilan keputusan bisnis, daya saing dan keberlanjutan usaha. Fokus Tahap Pertama adalah pada Kemitraan, Peningkatan Kualitas dan Manajemen. Berbagai kegiatan pendampingan yang dilaksanakan diantaranya adalah:

1. Peralatan produksi yang tidak menunjang nilai produk

2. Keterampilan dalam pewarnaan remasol terhadap produk hasil kerajinan yang masih sangat rendah

3. Keterampilan pengrajin bambu yang masih rendah terhadap teknik pewarnaan

4. Keterampilan menggunakan malam dingin masih rendah

5. Penguasaan teknologi yang rendah pada mitra

6. Pengetahuan peralatan dan teknologi tepat guna yang rendah

7. Kapasitas produksi terbatas

8. Biaya bahan baku yang harganya tergolong tinggi

9. Penanganan bahan baku kualitas rendah belum maksimal

10.Rendahnya pemanfaatan bahan baku menjadi produk bernilai

\section{HASIL DAN PEMBAHASAN}

1. Penyuluhan dan pengadaan peralatan pendukung proses produksi, yang memberikan dukungan pada peningkatan nilai produk. Pembuatan meja besi pada tenaga ahli las, pembelian bahan baku malam dingin, pemesanan screen Batik,

Tahap ini mitra berpartisipasi dalam memberikan masukan pada desain alat yang paling sesuai dalam proses produksi Batik menggunakan screan, mitra melakukan praktik pembuatan malam dingin, dan beberapa langkah lain, diantaranya adalah:

a. Pemilihan motif yang akan dicetak ke dalam screen Batik

Terdapat enam motif yang telah dicetak dalam screen untuk proses produksi jangka panjang diantaranya adalah: seragam sekolah, seragam pegawai negeri sipil, seragam haji, dan berbagai seragam lain yang dapat dikombinasi warna. Berikut motif yang telah dicetak diantaranya: 


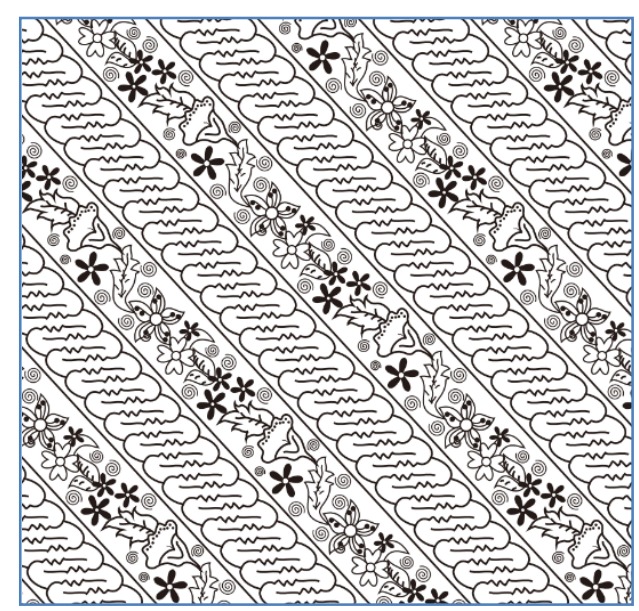

Gambar 1 Motif Parang Kembang

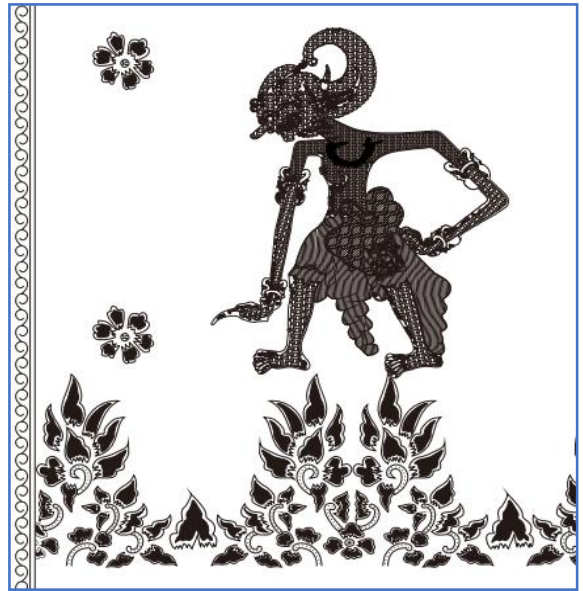

Gambar 2 Motif Wayang Suket

b. Penentuan ukuran screen yang akan digunakan dalam proses produksi batik

Ukuran screen yang direncanakan adalah panjang $270 \mathrm{~cm}$ dan lebarnya adalah $150 \mathrm{~cm}$, ukuran screen berbeda dengan ukuran gambar, panjang dan lebar screen adalah satu ukuran yang akan disesuaikan dengan ukuran meja, sementara ukuran gambar menyesuaikan dengan lebar kain yang akan di Batik.

c. Pembuatan Screen Motif

Tahap ini ada beberapa hal yang mitra harus pahami, bahwa motif original yang menjadi daya tarik Batik Purbalingga perlu dilakukan komputerisasi motif, yang awalnya hanya gambar tangan, kemudian di desain menggunakan corel, kemudian di cetak dalam screen, dan tidak bisa dilakuan secara keseluruhan oleh mitra, kemampuan mendesain ke dalam komputer dibutuhkan keahlian orang lain untuk mengimplementasikan hal tersebut. Hasil motif yang telah jadi diantaranya seperti:

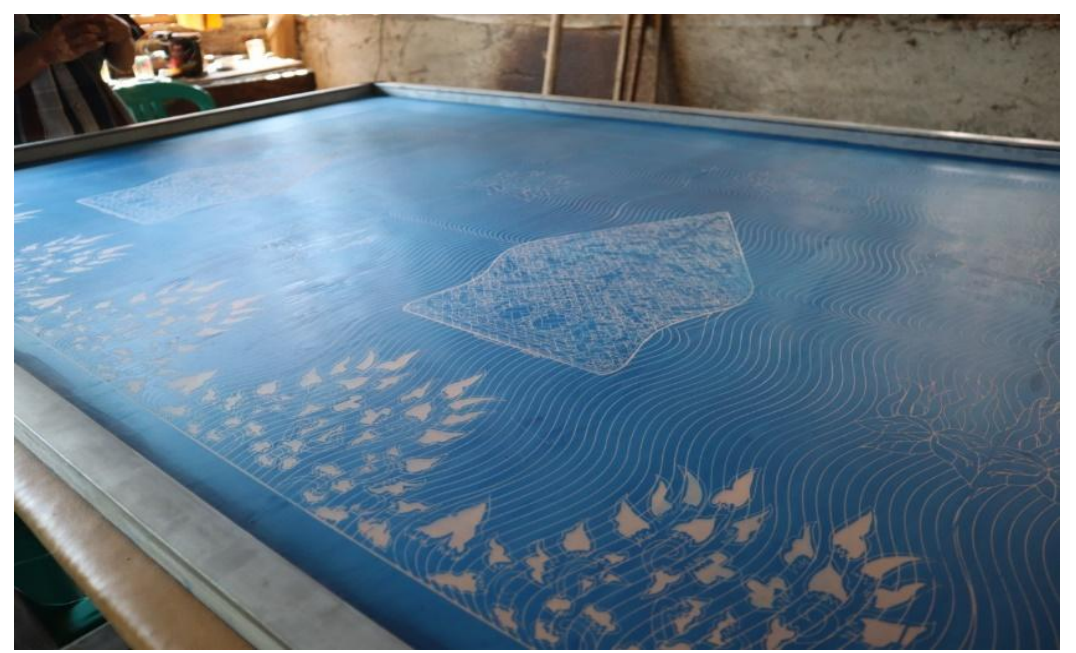

Gambar 3 Screen Wayang Suket 
Motif diatas adalah motif hasil desain yang telah dicetak ke dalam screen yang selanjutnya dapat dikerjakan untuk pembuatan batik. Ada bagian tertentu yang dapat kita tutup menggunakan lakban untuk mengurangi lebar dan panjang, dan motif disesuaikan dengan bahan yang ada.

d. Pendesainan Meja

Tahap ini membutuhkan kesepahaman antara mitra, Tim pelaksana terkait desain yang paling sesuai untuk proses produksi. Luar areal proses produksi, sangat menentukan terkait ukuran meja yang paling sesuai, disamping itu disesuaikan dengan ukuran screen sehingga memastikan bahwa lebar dan panjang screen tidak lebih lebar meja, karena akan mempersulit proses produksi.

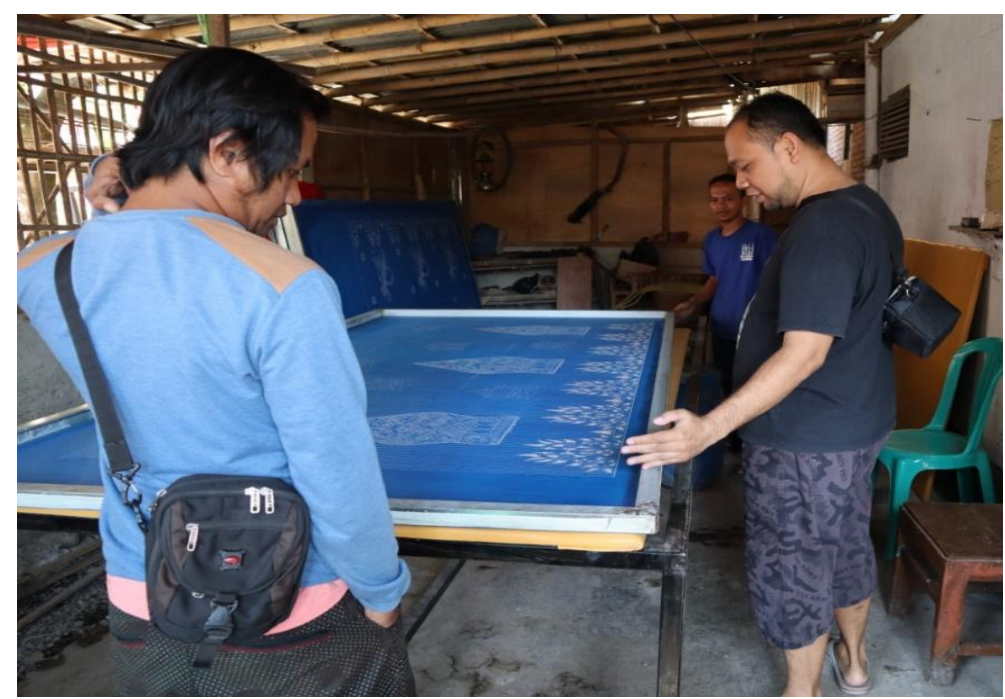

Gambar 4 Kegiatan Pengabndian PPPUD

Proses produksi ini membutuhkan perhitungan terkait berapa biaya pengembangan untuk penambahan screen baru, terdiri dari biaya desain dan cetak, biaya angkut, dan berbagai komponen biaya lain yang akan timbul saat pengembangan baru yaitu penambahan screen, proses ini telah di pahami mitra, untuk menunjang kelangsungan proses produksi terkait besarnya investasi pada screen baru.

Tabel 1 Biaya Produksi awal adalah sebagai berikut:

\begin{tabular}{|c|l|r|}
\hline No & \multicolumn{1}{|c|}{ Keterangan } & Jumlah \\
\hline 1 & $\begin{array}{l}\text { Kain 2,15 meter 300 lembar @ Rp. } \\
\text { 30.000,- }\end{array}$ & 9.000 .000 \\
\hline 2 & $\begin{array}{l}\text { Pewarna 4 Macam 18 Kg @ Rp. } \\
\text { 200.000,- }\end{array}$ & 3.600 .000 \\
\hline 3 & $\begin{array}{l}\text { Malam dingin Tamarin 17 Kg @ Rp } \\
50.000,-\end{array}$ & 850.000 \\
\hline 4 & Tenaga Kerja 30 hari @ 80.000 & 2.400 .000 \\
\hline & Jumlah & 15.850 .000 \\
\hline
\end{tabular}


Penggunaan malam dingin yang lebih efisien, dapat menakan proses produksi mencapai kurang lebih Rp. 4.050.000,- ini sangat menguntungkan bagi pengrajin, melihat data diatas penjualan 300 lembar kain batik, dengan harga Rp. 90.000,- maka penerimaan akan mencapai Rp, 27.000.000,- besarnya keuntungan yang diperoleh adalah sebesar Rp. 11.150.000,-.

Beberapa langkah yang perlu disiapkan adalah merekrut tenaga pemasaran untuk mendapatkan order dengan jumlah kapasitas produksi besar. Seperti melakukan penawaran ke sekolah dan pemerintah daerah untuk memberikan rekomendasi tentang Batik sebagai seragam dinas pada hari tertentu.।

2. Penyuluhan untuk meningkatkan pengetahuan pemanfaatan teknologi tepat guna, pengadaan mesin serut bambu, gerendra, pengadaan peralatan ini dapat dimanfaatkan untuk mempercepat proses produksi.

Semua peralatan telah dibeli dan lakukan uji coba untuk proses produksi, beberapa peralatan yang digunakan oleh pak Hendri dan Prianto diantaranya adalah:

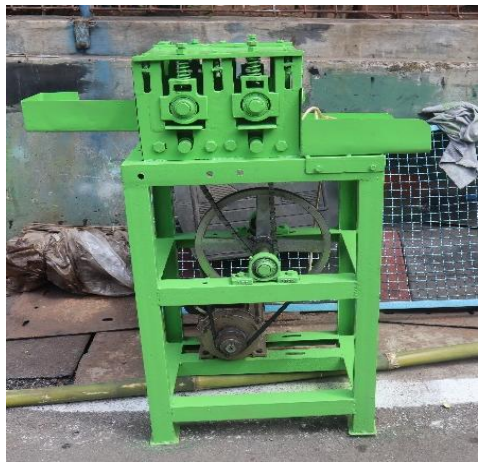

Gambar 5 Mesin Serut Bambu

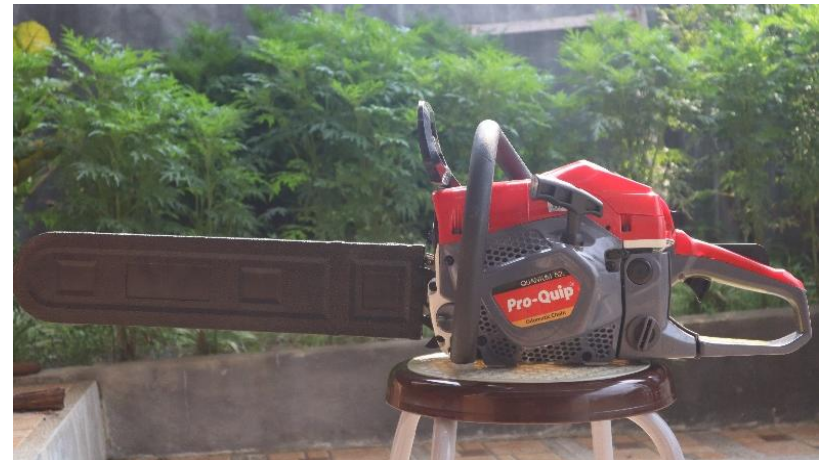

Gambar 6 Mesin Sengso

Partisipasi mitra untuk mendata inventaris peralatan produksi, dan pemeliharaan peralaatan produksi, tujuan pembelian peralatan ini adalah mempercepat proses produksi menggunakan perangkat teknologi baru yang selama ini masih jarang digunakan oleh mitra. Seperti mesin serut, mesin ini sangat bermanfaat untuk mempercepat proses serut bambu yaitu memisahkan antara kulit dengan inti bambu, dengan membuat media menjadi rata seperti potongan potongan kayu yang siap untuk disusun menjadi nampan, proses untuk menghaluskan menggunakan gerenda sehingga potongan bambu akan rapi dan halus.

Langkah evaluasi penambahan alat produksi pada mitra dapat memberikan dampak atau tidak dapat dilihat dari bagaimana pemanfaatan terhadap alat tersebut, apakah produksi menjadi semakin cepat atau sebaliknya. Kecepatan mesin irat untuk memproduksi potongan bambu adalah 1 menit dapat menghasilkan bahan mencapai 30 
potong ukuran $30 \mathrm{~cm}$ dengan ketipisan $3-4 \mathrm{~mm}$ bisa kita sesuaikan dengan ukuran yang kita inginkan. Untuk menghaluskan potongan tersebut per 1 menit mencapai 2 potong. Sehingga proses produksi diharapkan dapat lebih cepat dari proses sebelumnya.

3. Penyuluhan teknik pewarnaan remasol, baik pada media Batik maupun pada media bambu, langkah yang dilakukan adalah pengadaan bahan pewarna remasol, pembelian peralatan pewarnaan

Pewarnaan Remasol tergolong baru bagi pengrajin Batik dan bambu, pewarnaan ini sangat mudah, terdapat dua cara yang dapat dilakukan dalam proses pewarnaan yaitu menggunakan sistem colet atau celup, dengan kualitas warna yang sama. Dua kelompok mendapat pelatihan tentang pewarnaan Remasol, baik pewarnaan dalam media batik, maupun pewarnaan dalam media bambu:

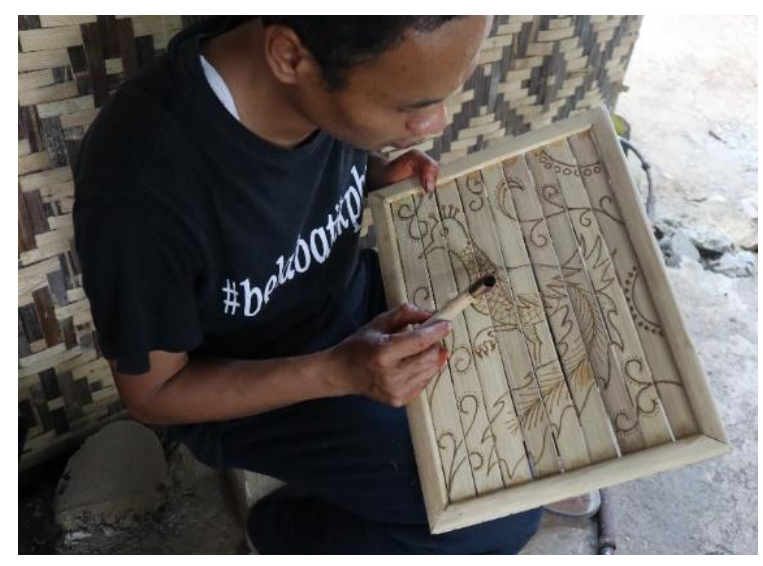

Gambar 7 Proses pembatikan pada media bambu

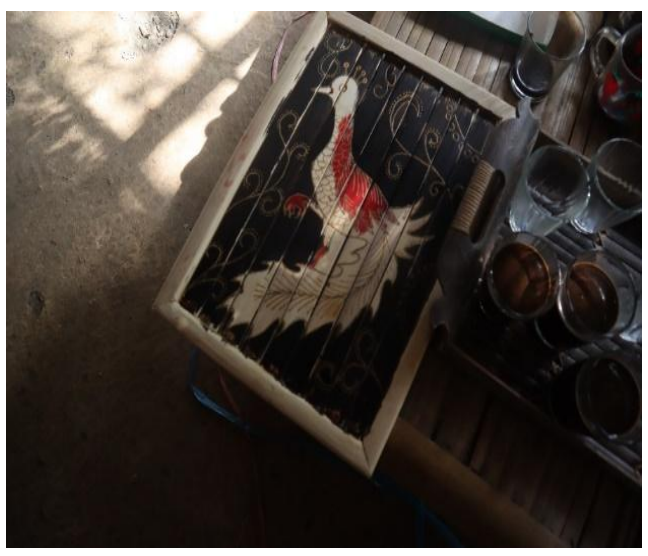

Gambar 8 Proses pewarnaan remasol

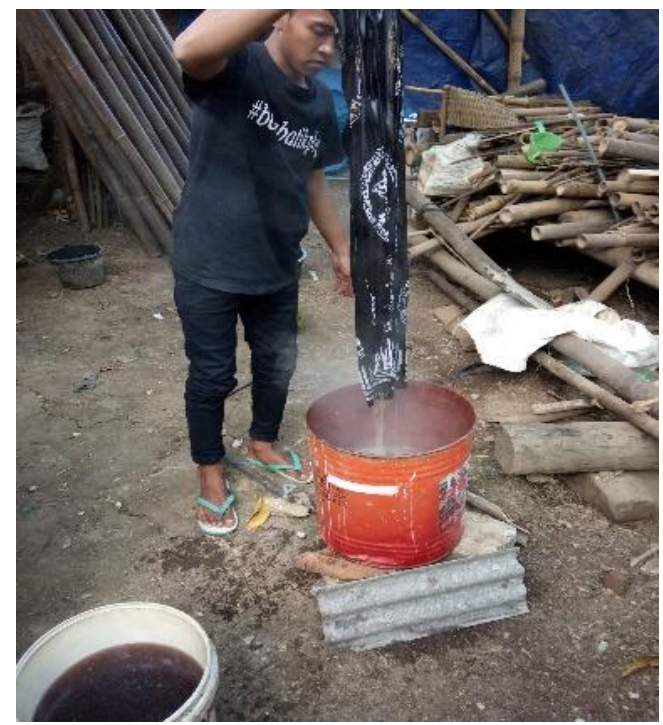

Gambar 9 Proses pencelupan batik 
Langkah Evaluasi, beberapa produk setelah dilakukan pewarnaan menggunakan remasol, adalah sebagai berikut:

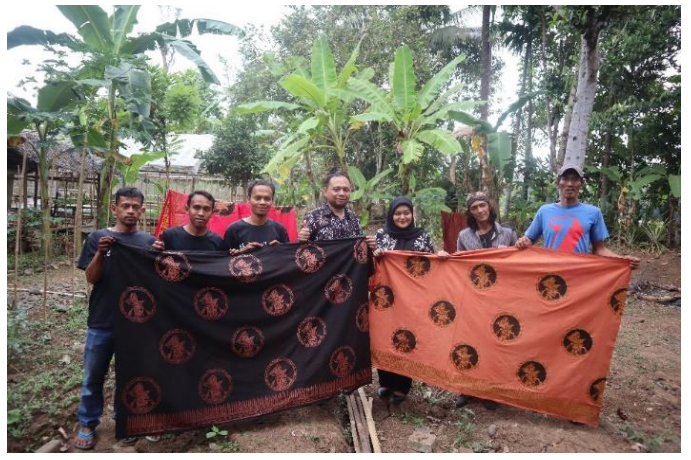

Gambar 10 Hasil pewarnaan Remasol

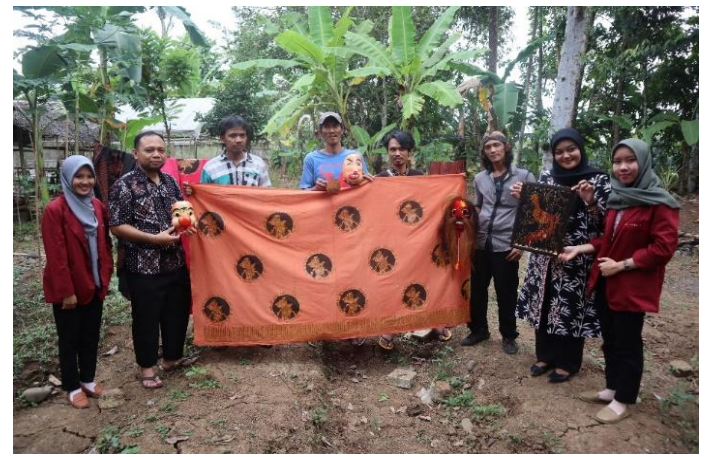

Gambar 11 Hasil pewarnaan remasol pada Bambu

4. Pelatihan untuk penanganan bahan baku batik printing malam bagi pengrajin batik dimana teknik ini dengan mencampurkan biji asam dicampur dengan mentega dan air panas, langkah yang dilakukan diantaranya adalah pembelian bahan baku mentega, pemasakan air panas, pembelian malam

Partisipasi mitra dalam kegiatan ini menentukan keberhasilan dari pelaksanaan produksi, transfer pengetahuan dari ketua kelompok terhadap beberapa anggota menjadikan tahapan proses produksi ini menjadi berkembang pada semua anggota mitra. Mitra dapat menemukan bahan malam dingin dengan bahan baku yang ada disekitar Purbalingga seperti biji asam dan mentega.

Langkah evaluasi jumlah malam dingin yang dibutuhkan sangatlah efisien, $1 \mathrm{Kg}$ malam dingin memerlukan pengeluaran biaya sebesar Rp. 45.000,- jumlah tersebut sangat cukup untuk memenuhi beberapa proses pembatikan, karena untuk per potong malam dingin dengan ukuran diantara 2 meter sampai 2,15 meter mencapai kurang lebih sebanyak 2 ons.

5. Pengadaan film atau screen ukuran besar $270 \mathrm{~cm} \times 150 \mathrm{~cm}$, teknologi ini akan memperccepat proses produksi printing dengan kapasitas 150 buah akan selesai dalam waktu 1 jam.

Mitra telah memperhitungkan biaya pengadaan screen paling tidak membutuhkan investasi mencapai Rp. 1.200.000,- per lembar dengan biaya pengiriman mencapai Rp. 800.000,-, berbagai kelemahan yang dimiliki bahwa untuk mendapatkan screen dengan ukuran besar, sangat sulit mendapatkan di daerah Purbalingga, namun 
tahap ini membutuhkan peningkatan skill yang berkelanjutan, sehingga proses produksi screen dapat dilakukan di Purbalingga.

Ukuran meja lebih luas dibandingkan dengan ukuran screen, ukuran meja sendiri dengan panjang 3,5 meter dan lebar 1,60 Meter, ukuran ini sudah mempertimbangkan lebar kain rata-rata dan adanya tempat space untuk kain yang belum di lakukan printing malam.

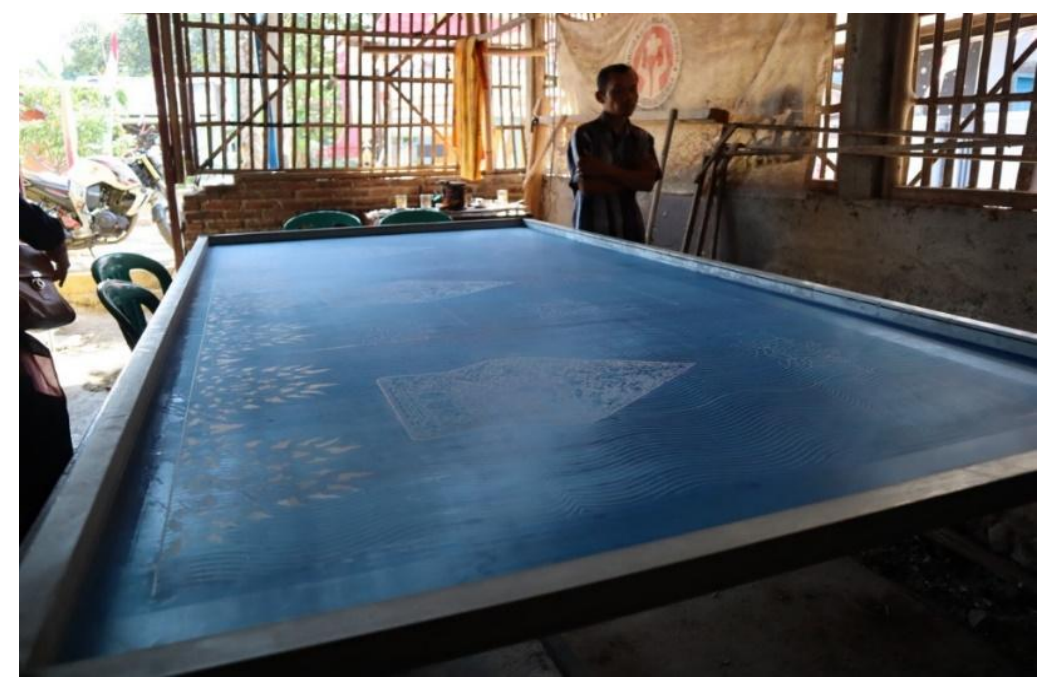

Gambar 12 Screen Wayang Suket

Langkah evaluasi jumlah screen awal yang dimiliki sekarang adalah 6 buah screen, ini digunakan untuk produksi seragam sekolah, seragam calon haji dan berbagai kebutuhan seragam lain, yang dapat memenuhi target satu orang dapat memproduksi kurang lebih 300 potong per bulan, dengan pengeluaran biaya yang signifikan.

6. Pelatihan dan penyuluhan untuk penanganan bahan baku untuk mitra Akar Wijaya, langkah yang dilakukan adalah pengadaan bahan baku lokal dan luar daerah, identifikasi kapasitas kebutuhan dan kemampuan sumber daya yang dimiliki

Bahan baku akar tersedia di berbagai daerah, baik di Purbalingga maupun dari tempat lain, beberapa hal yang perlu di perhatikan bahwa besarnya pengeluaran biaya untuk mengadakan bahan baku yang sering kali ada yang lebih murah dibandingkan dengan lokasi lain, keputusan yang harus diambil adalah memilih bahan baku murah dengan kualitas yang tidak berbeda jauh harganya, beberapa bahan yang tersedia namun perlu di lakukan sortir diantaranya seperti: 


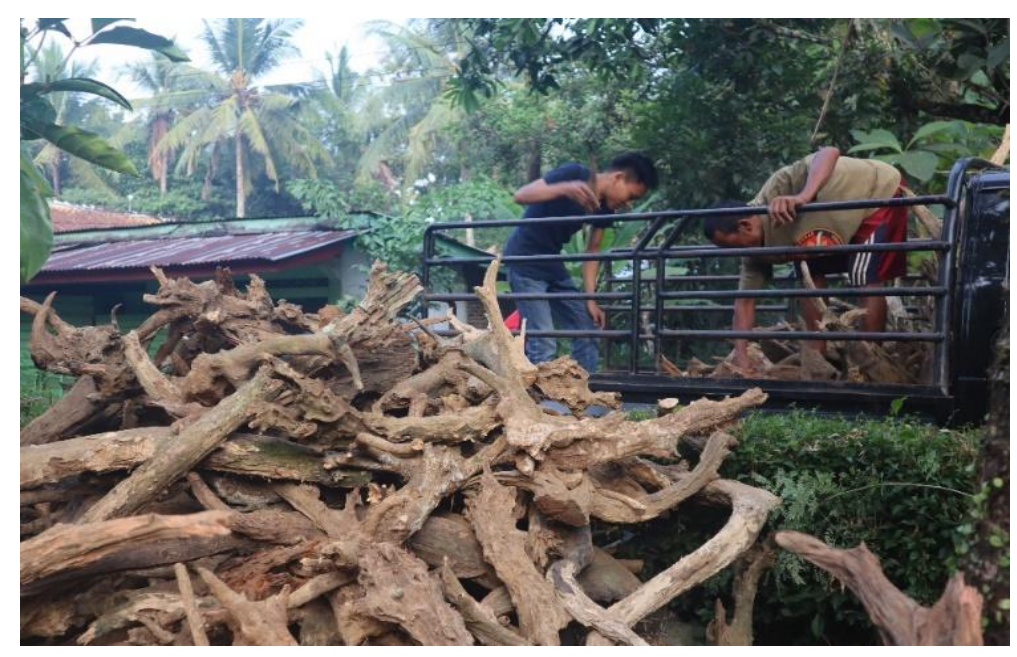

Gambar 13 Bahan baku akar kayu

Proses sortir dengan mempertimbangkan bagian tubuh dari masing masing karakter yang direncanakan seperti Groot, burung dan berbagai karakter lain diantaranya dapat dilakukan dengan memisahkan bahan yang memungkinkan menjadi bagian tertentu yang sesuai dengan karakter yang akan dibuat.

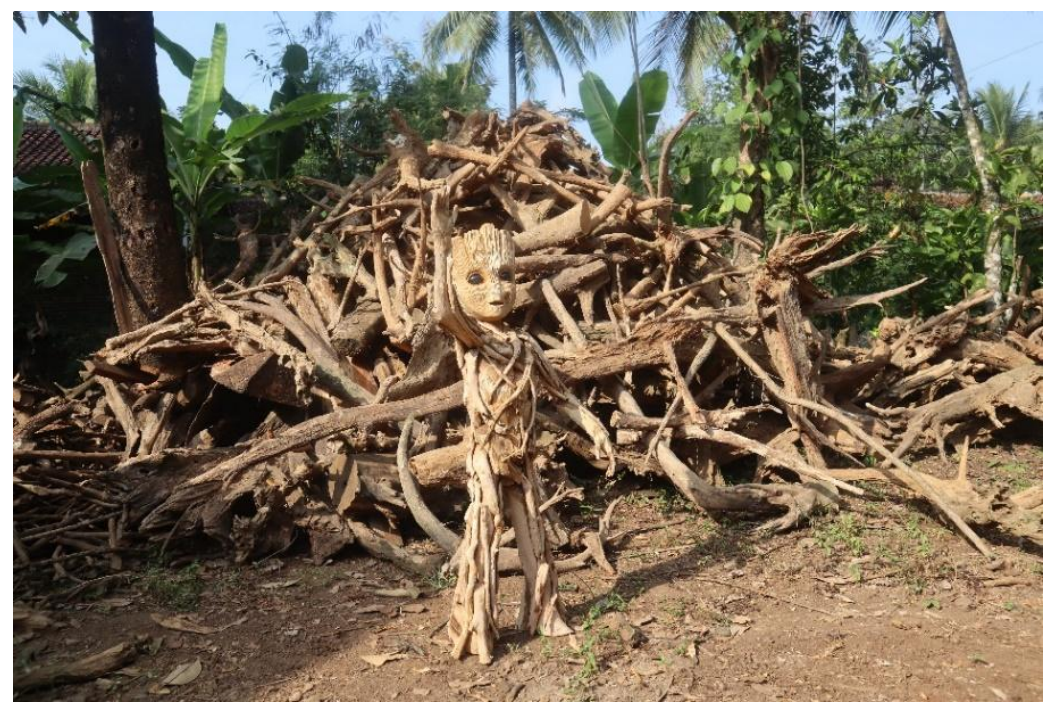

Gambar 14 Patung Akar Kayu

Langkah evaluasi kebutuhan bahan baku harus direncanakan, berapa kapasitas yang tersisa dan berapa kapasitas yang dibutuhkan untuk beberapa bulan ke depan, sangatlah penting untuk diperhitungkan. Sebagian pendapatan yang diperoleh minimal $20 \%$ harus diinvestasikan untuk pembelian bahan baku, hal ini dapat melalui ditabung atau dibelanjakan langsung para supplier akar, sehingga katersediaan bahan baku tetap terjaga. 
7. Pelatihan dan penyuluhan tentang penanganan bahan baku pada mitra Akar Wijaya, pemanfaatan bahan baku lokal sangat dibutuhkan, langkah yang dilakukan adalah pengadaan bahan baku lokal, pemisahan bahan baku lokal berkualitas baik dan bahan tidak terpakai dan membangun jaringan hilirisasi bahan baku.

Pemukiman penduduk dengan yang banyak tersedia berbagai macam akar yang dapat digunakan untuk memproduksi kerajinan patung ini, membutuhkan alat angkut yang digunakan untuk membawa dari satu tempat ke tempat yang lain untuk proses pengumpulan akar.

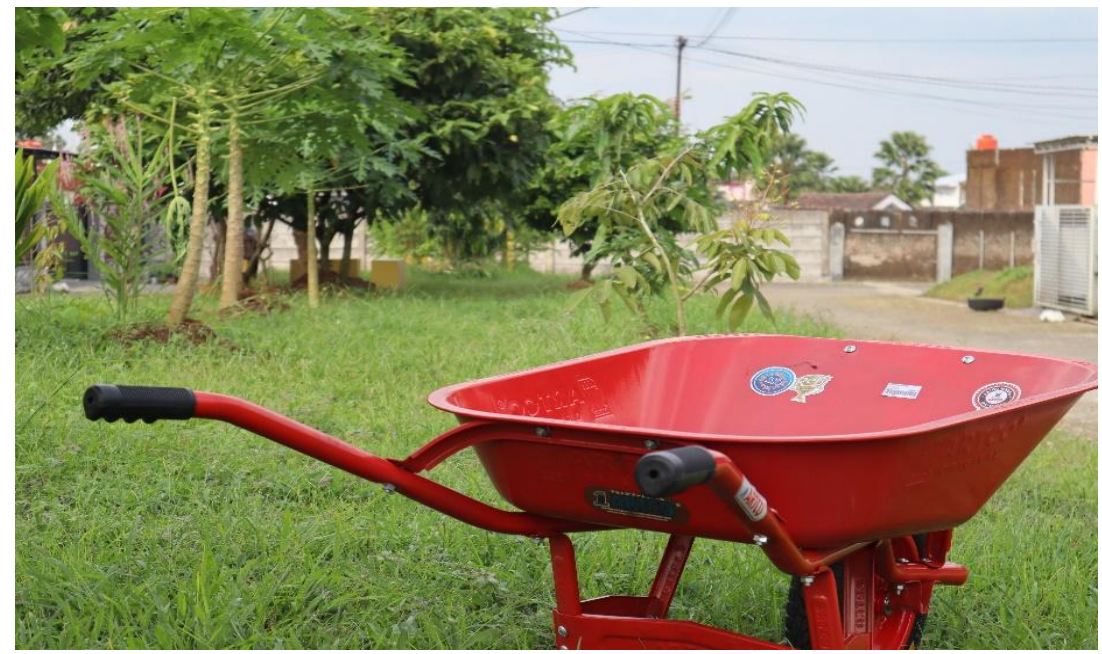

Gambar 15 Gerobak Dorong

Langkah evaluasi pengumpulan bahan baku lokal diperoleh dari pemberdayaan tenaga menganggur, seperti tenaga tani yang memiliki kelonggaran waktu, dapat memanfaatkan waktu luangnya untuk mencari akar kayu jati, dan berbagai jenis akar kayu lainnya di sekeliling tempat tinggal, sehingga dapat bernilai lebih tinggi dibandingkan sebagai kayu bakar.

8. Membentuk pola kemitraan ketiga mitra, penentuan jadwal pelaksanaan rutin pelatihan, penyusunan jadwal pelatihan pewarnaan

Pola kemitraan yang dijalankan adalah adanya saling transfer pengetahuan antara satu kelompok dengan kelompok yang lain melalui kegiatan pertemuan secara rutin; melakukan pelatihan untuk meningkatkan skill yang dibutuhkan oleh masing masing mitra. Pelatihan pembatikan pada media bambu memberikan peningkatan skill pada pengrajin bambu untuk meningkatkan nilai jual, sehingga produk hasil olahan bambu dapat bernilai lebih tinggi. 


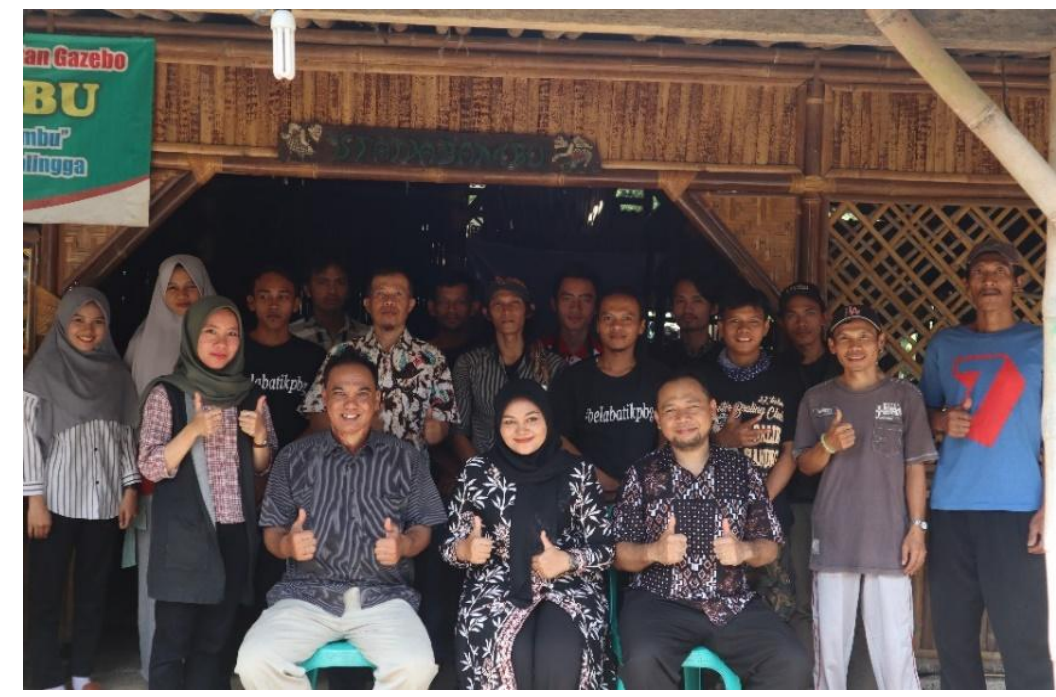

Gambar 16 Kegiatan Pengabdian PPPUD

Langkah evaluasi mitra membangun jaringan kemitraan dalam bidang produksi, pemasaran dan mengembangkanya pada jaringan yang lebih luas dengan Dinas UMKM Kabupaten Purbalingga.

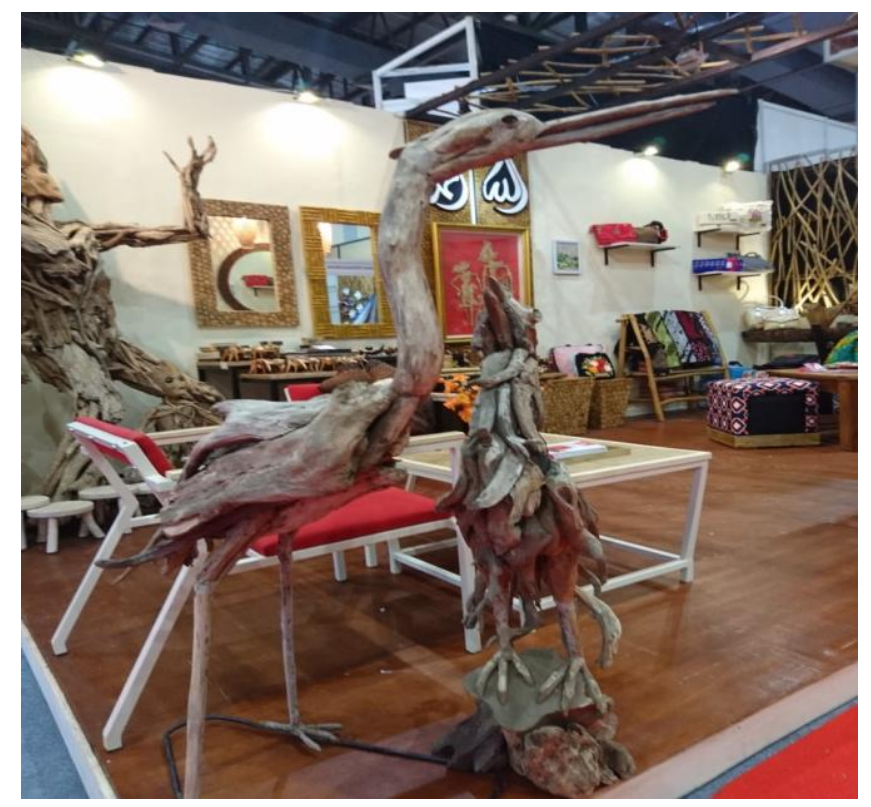

Gambar 17. Produk untuk kegiatan pameran Akar Wijaya

\section{KESIMPULAN}

Kegiatan penyelesaian masalah telah dilaksanakan dengan 8 (delapan) tahapan penyelesaian. Beberapa hal yang telah dicapai diantaranya adalah: peningkatan kuantitas peralatan produksi yang menunjang nilai produk; peningkatan skill sehingga meningkatkan keunggulan bersaing pada pengrajin dalam pewarnaan remasol terhadap produk hasil kerajinan; peningkatan keterampilan pengrajin bamboo. Selain keterampilan penggunaan mesin juga keterampilan peningkatan proses finishing sehingga nilai produk meningkat, 
keterampilan produksi menggunakan malam dingin yang semakin baik, penguasaan teknologi yang semakin baik; selain mitra memiliki alat baru yang lebih baik, pengetahuan peralatan dan teknologi tepat guna yang rendah, kapasitas produksi mitra meningkat; peningkatan pengetahuan mitra terkait bahan baku produk, selain aspek biaya pengadaan bahan baku sampai peningkatan kualitas bahan baku, sehingga akan menghasilkan produk berkualitas; penanganan bahan baku kualitas rendah maksimal; semakin tingginya pengetahuan mitra terhadap pemanfaatan bahan baku menjadi produk bernilai.

Saran terhadap pelaksanaan program peningkatan kualitas dan manajemen adalah denganadanya peningkatan kualitas produk. Kualitas produk harus ditunjang dengan peningkatan pemasaran. Semakin meningkat pemasaran semakin baik dan banyak produk yang diproduksi. Apabila pemasaran masih rendah, maka tidak memberikan dampak pada peningkatan keuntungan mitra. Sehingga perlu dirumuskan strategi baru untuk meningkatkan pasar, dan pengembangan usaha, sehingga pasar menjadi semakin luas dan omset mitra pun dapat berkembang secara berkelanjutan.

\section{UCAPAN TERIMA KASIH}

Kami sampaikan terima kasih kepada Rektor Universitas Peradaban dan Kemenristek Dikti sehingga pelaksanaan "Program Pengembangan Produk Unggulan" Kabupaten Purbalingga dapat berjalan lancar dan mitra pengabdian dapat meningkatkan keterampilan pemanfaatan teknlogi baru yang dibutuhkan untuk meningkatkan produksi dan omset penjualan.

\section{DAFTAR PUSTAKA}

[1] Ariyanto, D. C., \& MUDAKIR, Y. B. (2013). Analisis Daya Saing Sektor Unggulan dalam Struktur Perekonomian Provinsi Jawa Tengah Tahun 2010 (Doctoral dissertation, Fakultas Ekonomika dan Bisnis).

[2] En, T. K., \& Suryandi, F. A. J. M. (2012). Peranan Sistem Informasi Akuntansi Terhadap Pengendalian Intern Aktivitas Pembelian Bahan Baku Guna Mencapai Penyerahan Bahan Baku yang Tepat Waktu (Studi Kasus pada Perusahaan "X" Bandung). 2(6).

[3] Novandari, W. J. J. e. d. b. (2013). Pemetaan dan Analisis Kompetensi Inti UKM Batik di Kabupaten Purbalingga dengan Pendekatan Value Chain. 12(1).

[4] Setyorini, C. T., Pinasti, M., Rokhayati, H. J. I. J. o. B., Humanities, \& Technology. (2013). Strengthening the Internal Factors of Batik Cluster Smes in Indonesia: A Case of Six Districts in South-Central Java. 3(1), 21-28. 
[5] Suliyanto, S., Novandari, W., \& Setyawati, S. M. J. J. E. d. B. (2015). Persepsi Generasi Muda Terhadap Profesi Pengrajin Batik Tulis di Purbalingga. 18(1), 135-144.

[6] Wulandari, S. Z., Suwaryo, S., \& Indriati, S. J. P. (2017). Peningkatan Kapasitas Usaha Batik Cap Motif Khas Pesona Gua Lawa Bagi Kelompok Batik Sekarsari Purbalingga. $7(1)$ 